\title{
EFEKTIVITAS DANA BOS TERHADAP PENINGKATAN MUTU DI MADRASAH
}

\author{
Sumarni \\ Puslitbang Pendidikan Agama dan Keagamaan | Balitbang dan Diklat Kemenag RI \\ Jl. MH Thamrin No.06 Jakarta Pusat | Email: marni_ch@yahoo.com.au
}

\begin{abstract}
This study attempts to know the fund management of BantuanOperasionalsekolah (BOS/School Operational Assistance) in Madrasah Ibtidaiyah (MI) and Madrasah Tsanawiyah (MTs) and also its effectiveness in improving the education quality in madrasah. The research was conducted in 12 provinces with 144 MI and 98 MTs samples in total. The data were collected using instrument of questionnaires, interview guides, checklists, and being analyzed using SPSS Version 19. The research result shows that, first, the performance of BOS fund management has been very positive. The positive side of this BOS fund management is seen from the level of preparation, the implementation process, and activities after the implementation, its derivative impacts, and general evaluation toward the performance of BOS Team of the madrasah. Second, the BOS fund have avery positive impact towards the quality improvement of madrasah which is measured with the indicators of improved accreditation status of madrasah, increasing number of students, and the (decreasing) number of not-grade and drop-out students. The positive impact of BOS is also recorded from the achievement of madrasah students in many and various contests. In addition to that, the BOS fund is able to increase the ethos of school and learning spirit of the students.
\end{abstract}

Keywords: BOS funds, Madrasah quality

\begin{abstract}
Abstrak
Tulisan ini bertujuan untuk mengetahui bagaimana pengelolaan dana Bantuan Operasional Sekolah (BOS) di MI - MTs dan efektifitasnya dalam meningkatkan mutu pendidikan di madrasah. Penelitian dilakukan di 12 propinsi dengan jumlah sampel 144 MI dan 98 MTs. Data di kumpulkan dengan instrumen kuesionair, pedoman wawancara, daftar isian dan dianalisis dengan menggunakan spss versi 19. Hasil penelitian ini menunjukkan bahwa pertama, kinerja pengelolaan dana BOS sudah sangat positif. Sisi positif dari pengelolaan dana BOS ini terlihat dari jenjang persiapan, proses pelaksanaan, dan kegiatan pasca pelaksanaan, dampak turunannya, dan evaluasi umum terhadap kinerja Tim BOS madsarah. Kedua, dana BOS berdampak sangat positif terhadap peningkatan mutu madrasah yang terukur dengan indikator peningkatan status akreditasi madrasah, peningkatan jumlah siswa, dan jumlah siswa tingal kelas dan putus sekolah. Dampak positif BOS juga terrekam dari fakta jejak prestasi siswa madrasah di banyak dan variasi lomba. Selain itu, dana BOS mampu meningkat etos sekolah dan semangat belajar siswa.
\end{abstract}

Kata Kunci: Dana BOS, Mutu Madrasah

\section{PENDAHULUAN}

Pemerintah telah berupaya dalam meningkatkan mutu pendidikan melalui berbagai hal melalui kebijakan-kebijakan di bidang pendidikan. Kebijakan pembangunan pendidikan dalam kurun waktu 2004-2009 diprioritaskan pada peningkatan akses masyarakat terhadap pendidikan dasar yang lebih berkualitas melalui peningkatan pelaksanaan 
wajib belajar pendidikan dasar 9 tahun dan pemberian akses yang lebih besar kepada kelompok masyarakat yang selama ini kurang dapat menjangkau layanan pendidikan dasar.

Program Bantuan Operasional Sekolah (BOS) yang dimulai sejak Juli 2005 merupakan salah satu bentuk komitmen pemerintah dalam memberikan layanan pendidikan bagi seluruh peserta didik di tingkat pendidikan dasar, sehingga tidak ada lagi warga miskin yang tidak bisa mengikuti pendidikan karena tidak memiliki biaya. Bantuan Operasional Sekolah (BOS) merupakan program pemerintah untuk penyediaan biaya non personalia bagi satuan pendidikan dasar sebagai pelaksana program wajib belajar. Sesuai dasar kebijakannya, program BOS bertujuan meringankan beban masyarakat terhadap pembiayaan pendidikan, dan secara khusus BOS bertujuan untuk membebaskan seluruh siswa miskin di tingkat pendidikan dasar 9 tahun dari beban biaya operasional sekolah, kecuali pada rintisan sekolah bertaraf internasional dan nasional, serta untuk meringankan beban operasional pendidikan siswa di sekolah swasta. BOS juga bertujuan untuk mengurangi angka putus sekolah, meningkatkan APK siswa, serta memberi kesetaraan peluang bagi siswa yang kurang mampu pada MI/MTs untuk mendapat layanan pendidikan yang bermutu dan terjangkau. Ringkasnya, BOS bisa menjadi media penting untuk meningkatkan akses layanan pendidikan dasar yang terjangkau dan bermutu, dengan hasil akhirnya dapat mempersempit kesenjangan partisipasi sekolah antar kelompok masyarakat menurut tingkat penghasilan (kaya-miskin), dan antar wilayah (kota-desa).

Setelah program pemberian Dana BOS berjalan selama 5 tahun, pemerintah mulai tahun 2009 mengubah tujuan, pendekatan , dan orientasi BOS. Program BOS bukan hanya berperan untuk mempertahankan Angka Partisipasi Kasar (APK), tetapi harus juga berkontribusi untuk peningkatan mutu pendidikan dasar. Selain itu, dengan satuan biaya BOS yang telah dinaikkan secara signifikan, program ini menjadi pilar utama untuk mewujudkan pendidikan yang berkualitas.

Kebijakan pemberian dana BOS bukan tanpa kritik. Selama ini, skema pengalokasian penyaluran dana BOS per madrasah mengabaikan banyak faktor yang mengganggu kelancaran pengelolaan pendidikan. Saat ini pemerintah menyalurkan dana BOS berbasis jumlah siswa per madrasah. Dengan kata lain, jumlah siswa madrasah sangat mempengaruhi jumlah dana BOS yang diterima madrasah. Di sisi lain, jumlah guru dan pegawai negeri di madrasah swasta sangat membebani biaya personalia madrasah untuk gaji-honor gurupegawai honorer.Kontribusi, iuran sumbangan, tepatnya "pungutan" yang dibebankan pada orangtua siswa, juga mempengaruhi kemampuan finansial madrasah untuk menyelenggarakan pendidikan. Banyak madrasah favorit tetap mewajibkan kontribusi keluarga siswa, bahkan dengan jumlah yang besar untuk biaya pendidikan anak-anaknya. Di sisi lain, madrasah di basis komunitas kurang mampu mengalami kesulitan untuk mencari dana tambahan untuk membiayai proses pendidikan. Dengan variasi latar belakang seperti ini, kemampuan finansial madrasah untuk membiayai penyelenggaraan pendidikannya juga berbeda. Karena alasan keterbatasan dana, madrasah swasta, terutama dengan jumlah siswa yang sedikit, umumnya tetap menggunakan dana BOS untuk biaya hajat personalia, walaupun hal itu bertentangan dengan pedoman teknis penggunaan dana BOS.

Kiranya masih banyak persoalan terkait dengan pengelolaan dana BOS ini. Seberapa besar pengaruh jumlah guru swasta di madrasah mempengaruhi penggunaan dana BOS untuk belanja pegawai? Apakah pemanfaatan dana BOS berdampak positif terhadap kualitas madrasah yang terukur dengan sejumlah indikator standar tetapi substansial? Apakah pengelolaan dana BOS sudah berjalan dengan baik? Atau justru masih 
menyulut atmosfer pembelajaran yang kurang kondusif di madrasah? Apakah pengelolaan dana BOS sudah transparan dan akuntabel? Itulah beberapa pertanyaan yang perlu dicari jawabannya.

Sudah banyak penelitian tentang pengelolaan dana BOS ini. Hasil sejumlah penelitian tersebut memang bervariasi. Variasi temuan ini nampaknya bersumber dari keragaman konteks, pendekatan dan metode penelitian. Dari titik kekurangan dan kelemahan studistudi yang ada, maka sangat diperlukan model pendekatan survei dengan jumlah sampel dan cakupan wilayah studi yang luas dan representatif untuk mengevaluasi pengelolaan dana BOS, dan pengaruhnya terhadap peningkatan mutu madrasah dan siswa. Selain itu, formula pengalokasian dana BOS yang sesuai ketentuan juga harus dikritisi dari sisi keterkaitannya dengan kemampuan finansial madrasah dalam membiayai penyelenggaraan pendidikannya. Diharapkan penelitian ini dapat memberikan gambaran yang lebih jelas bagaimana pengelolaan dana BOS di madrasah dan dampaknya terhadap peningkatan mutu madrasah.

Fokus masalah dalam studi ini adalah kinerja pengelolaan dana BOS, dan pengaruhnya terhadap mutu pendidikan madrasah (MI-MTs) dengan rumusan pertanyaan sebagai berikut: 1) Bagaimana pengelolaan program BOS di MI/MTs?, 2) Apakah program BOS mampu meningkatkan mutu pendidikan MI/MTs?, dan 3) Apa kendala dan tantangan pengelolaan dana BOS?

Hasil studi ini diharapkan dapat memberi informasi ke semua pihak pemangku kebijakan dan kepentingan yang terkait dengan pengelolaan BOS, yaitu tentang kondisi objektif pengelolaan dana BOS, serta dampaknya terhadap peningkatan mutu pendidikan siswa dan madrasah. Studi ini juga dapat memberikan masukan bagi pemerintah dalam mengambil kebijakan turunan dan lanjutan yang terkait dengan pengelolaan dana BOS di masa mendatang, terutama untuk merumuskan formula pengalokasian dan pendistribusian dana BOS yang lebih kontekstual dan berkeadilan bagi madrasah dan masyarakat luas. Bagi madrasah dan stakeholder, hasil penelitian ini menginformasikan manfaat dan efektivitas BOS dalam meningkatkan mutu pendidikan siswa-madrasah. Secara praktis, hasil penelitian ini diharapkan menjadi dasar evaluasi untuk merumuskan kebijakan turunan terkait perencanaan dan pelaksanaan dana BOS di level madrasah.

\section{Kajian Teroritik}

\section{Pembiayaan Pendidikan}

Satu komponen instrumental penting dalam proses penyelenggaraan pendidikan adalah unsur biaya. Biaya pendidikan tidak bisa diabaikan dalam penyelenggaraan pendidikan, karena ia menjadi satu faktor penting yang mempengaruhi kualitas proses dan hasil akhir penyelenggaraan pendidikan. Pendidikan yang bermutu sulit dapat berjalan baik tanpa dukungan biaya yang memadai. Dilihat dari sudut pandang ekonomi, tidak mungkin ada kegiatan pendidikan tanpa biaya. Biaya itu diperlukan untuk memenuhi beragam kebutuhan yang berkenaan dengan keberlangsungan proses pendidikan. Di sini, ketersediaan biaya sangat menentukan capaian tujuan dan target pendidikan.

Biaya pendidikan mencakup banyak anasir. Supriadi mengartikan biaya (cost) pendidikan sebagai semua jenis pengeluaran yang berkenaan dengan penyelenggaraan pendidikan, baik dalam bentuk uang, barang atau tenaga jasa (yang dapat dihargakan dengan uang). ${ }^{1}$ Contohnya adalah iuran siswa, biaya sarana dan prasarana fisik, buku sekolah dan honor jasa guru/tenaga kependidikan lainnya.

Menurut Peraturan Pemerintah Republik Indonesia Nomor 48 Tahun 2008, beban

${ }^{1}$ Supriadi. 2004. Satuan Biaya Pendidikan Dasar dan Menengah. Bandung: PT Remaja Rosda-karya, h. 4.

EDUKASI Volume 12, Nomor 1, Januari-April 2014 
pendanaan pendidikan menjaditanggungjawab bersama pemerintah, pemerintah daerah dan masyarakat. Harus diakui bahwa pendidikan adalah proses panjang dan berkelanjutan untuk pengembangan potensi sumberdaya insani peserta didik dengan kebutuhan dana yang tidak sedikit. Sedangkan dana BOS adalah satu bentuk alokasi biaya tambahan pendidikan dan sifatnya spesifik, dan hanya untuk melengkapi kekurangan biaya yang ada terutama untuk hajat non personalia.

Dalam kaitan ini, Bray menegaskan bahwa pembiayaan pendidikan menyangkut sumber biaya, baik dari pemerintah atau masyarakat, dan alokasi belanja untuk proses belajarmengajar, termasuk pengeluaran madrasah untuk gaji dan berbagai layanan di setiap jenis madrasah. ${ }^{2}$

Dalammanajemen, biaya pendidikan dibagi menjadi 3 jenis, yaitu biaya satuan pendidikan, biaya penyelenggaraan dan/atau pengelolaan pendidikan, serta biaya pribadi peserta didik. ${ }^{3}$ Pertama, biaya satuan pendidikan adalah biaya penyelenggaraan pendidikan pada tingkat satuan pendidikan yang meliputi (1) biaya investasi yang mencakup biaya penyediaan sarana dan prasarana, pengembangan sumberdaya insani, dan modal kerja tetap, (2) bantuan biaya pendidikan yang diberikan kepada peserta didik yang orangtua/walinya tidak-kurang mampu, (3) beasiswa dalam wujud bantuan dana pendidikan yang diberikan kepada peserta didik yang berprestasi, dan (4) biaya operasional. ${ }^{4}$ Biaya operasional satuan pendidikan menurut Peraturan Pemerintah Nomor 19 Tahun 2005 tentang BSNP, meliputi (1) gaji guru dan tenaga kependidikan, dan segala tunjangan yang melekat pada gaji,

2 Marl Bray. 1996. Decentralization of Education: Community Finnacing. Washington DC: World Bank

${ }^{3}$ Petunjuk Teknis.2012. Pelaksanaan Bantuan Operasional Sekolah (BOS) pada Madrasah Negeri Tahun Anggaran 2012. Jakarta: Direktorat Jenderal Pendidikan Islam, Kementerian Agama, hal. 10.

${ }^{4}$ Penjelasan tentang teknis dan komponen biaya satuan pendidikan yang dialokasi pemerintah, silahkan lihat Rencana Straregis Kementerian Pendidikan Nasional, 2010-2014.
(2) bahan atau peralatan pendidikan habis pakai, dan (3) biaya operasional pendidikan tidak langsung yang berupa air, daya listrik, jasa telekomunikasi, pemeliharaan sarana dan prasarana, transportasi, konsumsi, uang lembur, pajak, asuransi dan lainnya. Kedua, biaya penyelenggaraan dan/atau pengelolaan pendidikan adalah biaya penyelenggaraan dan/atau pengelolaan pendidikan oleh pemerintah, pemerintah provinsi, pemerintah kabupaten/kota, atau penyelenggara/satuan pendidikan yang didirikan masyarakat. Ketiga, biaya pribadi peserta didik adalah biaya personal yang meliputi biaya pendidikan yang harus dikeluarkan peserta didik untuk dapat mengikuti proses pembelajaran secara teratur dan berkelanjutan.

Pembiayaan pendidikan harus dirancang lengkap, apik dan sistematis. Penyusunan pembiayaan pendidikan terdiri atas aspek (1) prosedur penganggaran; (2) akuntansi keuangan; (3) pendistribusian; (4) investasi; dan (5) pemeriksaan. ${ }^{5}$ Satu hal yang terpenting dalam penyusunan anggaran pendidikan adalah usaha, prosedur dan mekanisme. Semua harus dirancang dan dilaksanakan dengan baik agar dana bisa dimanfaatkan secara efisien dan efektif, dialokasikan serta disalurkan dengan tepat sasaran dan tepat guna, sesuai dengan skala prioritas. Sehingga semuanya dapat mendukung seluruh proses penyelenggaraan pendidikan yang bermutu, dan dapat menghasilkan lulusan yang berkualitas.

Pengelolaan dana pendidikan harus dilakukan secara hati-hati. Keputusan Menteri Pendidikan Nasional Nomor 053/U/2001 menegaskan bahwa pengelolaan dana pendidikan termasuk BOS harus dilaksanakan secara transparan dan akuntabel. Untuk hajat transparansi dan akuntabilitas pengelolaan dana pendidikan, hal-hal berikut perlu disusun dan dilakukan; (1) sistem pengendalian, (2) pengawasan dan (3) pemeriksaan pembiayaan pendidikan. Pertama, pengawasan adalah

${ }^{5}$ Rebore. 1985. Educational Administration: A Management Approach. Englewood Cliffs: Prentice Hall hal. 116. 
proses pengamatan terhadap pelaksanaan semua kegiatan organisasi untuk menjamin agar seuruh pekerjaan yang telah dan sedang dilakukan sesuai rencana. Menurut Syafrudin, pengawasan difungsikan untuk mengevaluasi kinerja pelaksanaan anggaran, termasuk kemungkinan penyimpangannya dari rencana awal. $^{6}$

Ada dua jenis pengawasan terhadap pembiayaan pendidikan, yaitu pengawasan administratif dan manajerial. Simanjuntak menegaskan bahwa pengawasan model pertama meliputi seluruh kegiatan pada semua unit organisasi, level dan bagian, dengan tujuan supaya keputusan yang dibuat (dalam bentuk rencana) dijalankan sesuai dengan kebijakan yang ditetapkan. ${ }^{7}$ Pengawasan manajerial, model kedua, lebih spesifik, dan khusus, yang hanya berlaku bagi suatu unit tertentu, atau fase tertentu dari rangkaian total pelaksanaan pendidikan. Meskipun lingkup pengawasan manajerial relatif terbatas, dan lebih spesifik dibanding pengawasan administratif, tetapi ia memiliki makna dan tujuan yang sama, yaitu untuk mencegah semaksimal mungkin segala wujud peristiwa penyimpangan dan penyelewengan pembiayaan dari rencana semula.

Pengawasan harus dilakukan secara holistik, integratif dengan melibatkan banyak pihak. Pelaksanaan pengawasan harus bertumpu pada pengawasan struktural dan sosial. Kelanjutan dari pengawasan holistik dan integratif terhadap pembiayaan pendidikan harus dapat dinilai secara transparan, dan terukur oleh pemerintah dan masyarakat dengan standar yang jelas, apalagi di era yang penuh keterbukaan. Kegiatan yang menggunakan sumber dana publik, walaupun jumlahnya relatif terbatas, seperti BOS, mutlak memerlukan pengawasan dan pengendalian, agar semua komponen sistem operasi mampu

${ }^{6}$ Syafrudin. 2003. Manajemen Mutu Terpadu dalam Pendidikan. Jakarta: Grasindo. hal. 86.

Simanjuntak. 1998. Pengantar Sumber Daya Manusia. Jakarta: FEUI, hal. 135. bergerak efektif dan efisien. Pengawasan terhadap pembiayaan bisa ditempuh dengan beragam cara, baik di jalur internal atau internal, dan dapat pula dilakukan secara struktural atau fungsional yang mencakup pemeriksaan, pembinaan dan evaluasi. Analisis laporan kegiatan dengan rincian satuan pendanaan bisa membantu fungsi pengawasan. Ringkasnya, dalam konteks pengelolaan pembiayaan, pengawasan dan pengendalian penting dilakukan agar sumberdaya finansial yang tersedia dapat dimanfaatkan secara optimal dan sesuai sasarannya.

Proses pengawasan terhadap pembiayaan pendidikan terdiri dari tiga tahapan, yaitu menetapkan standar pelaksanaan, pengukuran pelaksanaan pekerjaan dibandingkan dengan standar yang ditetapkan, dan menentukan penyimpangan pelaksanaan dari standar rencana. Dalam kaitan ini, petunjuk teknis pengawasan penggunaan dana BOS telah disusun oleh pemerintah, minimal tim manajemen BOS tingkat pusat. Normatifitas isi petunjuk teknis tersebut sangat detail, dan imperatif, terutama di level penggunaan BOS seperti dijelaskan di atas. Evaluasi pelaksanaan dana BOS dalam penelitian ini akan dievaluasi dari sudut kriteria dan prosedur ini.

Untuk mendukung sistem pengendalian terpadu perlu diadakan sistem monitoring pelaksanaan pembiayaan pendidikan. Monitoring bukan sekedar pelaporan, tetapi ia sebagai sebuah sistem untuk mengikuti secara seksama dan kritis seluruh proses pelaksanaan semua rangkaian program dan proyek pembiayaan terutama penggunaan dana BOS. Sistem monitoring secara hipotetis akan berjalan efektif jika ia disisipkan ke seluruh sistem perencanaan, penyusunan program, penganggaran dan evaluasi pelaksanaan. Monitoring akan lebih utuh dan sempurna jika ia dibuat dalam bentuk laporan dengan data yang akurat, relevan dan terkini.

Pengelolaan biaya menyangkut penggunaan danayang diamanatkanguna mendanai program dan kegiatan, dengan dana khusus seperti BOS. 
Setiap kegiatan yang dilakukan pengelola harus dapat dipertanggungjawabkan, baik dalam konteks program atau penyaluran dana. Karenanya, pengelolaan biaya harus akuntabel. Akuntabilitas adalah mutu rasa tanggungjawab, sehingga ia bisa memuaskan pihak lain. Makna yang terkadung di dalam akuntabilitas adalah kecocokan hasil pelaksanaan dengan peran dan fungsi ideal, penjelasan dan pertimbangan kepada orang lain tentang tindakan dan keputusan yang diambil terkait dengan pembiayaan pendidikan. Ringkasnya, aspek yang terkandung dalam akuntabilitas adalah terutama rasa puas, dan kepercayaan dari pihak lain; model kontrol dan kriteria ukuran. Rasa puas dari pihak lain dapat terwujud jika menurut kenyataan, seluruh kinerja madrasah mampu memenuhi apa-apa yang telah ditentukan di jenjang perencanaan, tepat waktu, atau sesuai dengan kriteria yang diinginkan dan tercermin dalam acuan dan standar pengawasan yang dilakukan oleh pihak lain.

Dengan demikian, akuntabilitas adalah suatu keadaan kinerja petugas pengelola biaya yang mampu bekerja dan memberi hasil kerja optimal sesuai kriteria yang ditentukan, dan akhirnya memberi rasa puas pihak-pihak yang berkepentingan. Supriadi merinci lebih detail langkah-langkah strategis untuk menentukan aspek dan indikator akuntabilitas. Langkahlangkah tersebut adalah (1) mengembangkan kriteria kinerja untuk semua dan setiap program yang direncanakan; (2) menyiapkan pemeriksaan berkas untuk mengukur kinerja; serta (3) menyiapkan laporan ke masyarakat tentang hasil pengukuran dan evaluasi. ${ }^{8}$ Ditegaskan juga bahwa akuntabilitas adalah peningkatan sikap tanggungjawab pengelola yang meliputi (1) penggunaan sumberdaya yang efisien dan efektif; (2) kesesuaian antara tujuan, hasil dan kegiatan fungsional, dengan nilai-nilai moral, etika, sosial dan (3) kepedulian terhadap peningkatan mutu yang berkelanjutan sesuai dengan tuntutan pihak yang berkepentingan.

\footnotetext{
${ }^{8}$ Op.cit, hal. 3
}

Kualitas akuntabilitas pengelolaan biaya pendidikan bisa ditegakkan dan tercermin dari keberadaan pembukuan, pemeriksaan dan pelaporan. Pembukuan bertujuan agar penggunaan dana yang telah dirancang dapat memberi hasil yang maksimal, efisien dan efektif. Untuk melengkapi pembukuan, juga diperlukan pemeriksaan terhadap pelaksanaan pembiayaan. Secara konseptual, pemeriksaan keuangan adalah rangkaian kegiatan penelitian penggunaan dana anggaran. Pemeriksaan keuangan bertujuan menilai apakah dana yang tersedia digunakan secara efisien atau justru menyimpang dari ketentuan yang telah ditetapkan.

Pemeriksaan kinerja keuangan merupakan kegiatan audit, yang terdiri atas dua kegiatan utama; pre-audit dan post-audit. Preaudit dilakukan sebelum pembayaran atau transaksi keuangan dilakukan. Pre-audit disebut juga pemeriksaan internal, karena pihak yang menjalankan fungsi pre-audit adalah pelaksana anggaran sendiri. Media yang dapat digunakan untuk keperluan pre-audit seperti sistem penjatahan atau penentuan ongkos. Pelaksanaan pre-audit erat kaitannya dengan pembukuan. Sedangkan post-audit adalah pemeriksanaan keuangan yang dilakukan pasca penyelesaian dan pembukuan transaksi keuangan. Wujud post-audit adalah pemeriksaan atas segala wujud dan jenis transaksi keuangan, catatan pembukuan, dan memuat seluruh laporan hasil pemeriksaan. Pelaksanaan post-audit mencakup unsur legalitas, ketelitian dan pertanggungjawaban keuangan dari pengguna anggaran.

Pembukuan dan pemeriksanaan bisa memberi informasi mengenai status finansial suatu lembaga. Sedangkan pelaporan menyangkut kegiatan menebar informasi keuangan guna meningkatkan pemahaman terhadap lembaga, dan untuk keperluan pengambilan keputusan terhadap kegiatan yang dilaksanakan. Pelaporan dapat dilakukan secara eksternal atau internal. Untuk mewujudkan peningkatan standar kualitas pelaporan 
pembiayaan tepat waktu, transparan dan komprehensif di institusi pemerintahan, telah diterbitkan sistem panduan pelaporan keuangan dalam wujud Peraturan Pemerintah bidang Standar Akuntansi Pemerintahan, termasuk pelaporan penggunaan dana Bantuan Operasional Sekolah (BOS). Sistem ini menjadi pedoman utama dalam proses akuntansi transaksi keuangan pemerintah yang diperlukan untuk mendukung hajat pimpinan, sebagai pedoman pengambilan keputusan di tahun anggaran berjalan, atau laporan keuangan guna pertanggungjawaban pelaksanaan anggaran sesuai peraturan perundang-undangan, termasuk pelaporan penggunaan BOS.

Secara total, dari perspektif manajemen pengelolaan pembiayaan, penggunaan dana BOS di madrasah harus didasarkan pada kesepakatan dan keputusan bersama antara anggota tim manajemen BOS madrasah, dewan guru dan komite. Sedikitnya ada empat hal fundamental yang harus diperhatikan dalam penggunaan dana BOS yaitu, efisiensi, efektivitas, transparansi dan akuntabilitas. Pertama, efisien adalah dana yang didapatkan madrasah digunakan sebaik-baiknya dengan memperhatikan kebutuhan, dan ketepatan sasaran penggunaan dana BOS. Kedua, efektivitas adalah kelanjutan dari dimensi efisiensi. Efektivitas terukur dari standar penggunaan dana BOS dalam membantu madrasah merealisasikan program yang direncanakan. Ketiga, transparansi adalah keterbukaan dalam pengelolaan dana BOS, di ranah dan level perencanaan, penggunaan, dan pelaporan. Pelibatan guru, komite sekolah dan orangtua/wali murid adalah satu wujud transparansi. Keempat, akuntabilitas terukur dengan indikator sejauhmana pengelolaan dan penggunaan dana BOS dapat dipertanggungjawabkan secara moral dan formal.

Dari penjelasan teoritis di atas nampak beberapa butir alur analisis penelitian ini. Pertama, saat dana terbatas, dan beban membayar honor guru dan tenaga kependidikan terus

meningkat, maka pihak madrasah diyakini akan mengoptimalisasi penggunaan dana BOS untuk belanja pegawai. Karenanya, jumlah guru dan tenaga pendidikan honorer di madrasah akan berdampak signifikan pada optimalisasi dana BOS untuk membayar honor guru dan tenaga kependidikan honorer. Kedua, sesuai dasar normatif dan moral legislasi BOS, dana BOS diyakini akan lebih banyak disalurkan untuk membantu siswa kurang mampu, dana BOS digunakan untuk membantu madrasah penyelenggaraan proses belajar-mengajar. Terakhir, penggunaan dana BOS akan lebih diprioritaskan untuk mendukung kegiatan siswa, karena sesuai tujuan dasarnya, dana BOS, salah satunya diprioritaskan untuk mendukung kegiatan kesiswaan.

\section{Pengertian Mutu Pendidikan}

Mutu memiliki konotasi yang beragam di benak banyak orang. Semuanya bergantung pada orang yang memakainya. Dalam bahasa Inggris, mutu adalah quality. Kata ini berasal dari bahasa latin yakni qualis yang secara leksikal bermakna what kind of (tergantung kata yang mengikutinya). Berikut beberapa konsep mutu yang diutarakan sejumlah pakar. ${ }^{9}$ Menurut Juran, jika disematkan pada satu produk, mutu ialah kecocokan penggunaan produk (fitness for use) dimaksud untuk memenuhi hajat dan kepuasan pelanggan. Kecocokan penggunaan produk itu didasarkan atas lima ciri utama; (a) teknologi; yaitu kekuatan; (b) psikologis, yaitu rasa atau status; (c) waktu, yaitu kehandalan; (d) kontraktual, yaitu ada jaminan mutu produk; dan (e) etika, yaitu sopan santun.

Menurut Crosby, mutu adalah conformance to requirement (kesesuaian sesuatu dengan halhal yang disyaratkan). Suatu produk memiliki mutu, jika ia sesuai dengan standar, kriteria mutu yang ditentukan. Standar mutu meliputi anasir bahan baku, proses produksi, dan produk jadi. Sementara menurut Feigenbaum, mutu

${ }^{9}$ Haris dan Nurhayati B. 2010. Manajemen Mutu Pendidikan. Jakarta, h. 84. 
adalah kepuasan utuh pelanggan (full customer satisfication). Suatu produk dinilai bermutu jika bisa memberi kepuasan sepenuhnya kepada konsumen, yaitu sesuai dengan harapan konsumen atas produk yang dihasilkan.

Mengutip pendapat Sallis, Usman menjelaskan bahwa mutu bisa dipilah ke dalam konsep absolut dan relatif. ${ }^{10}$ Mutu absolut adalah kualitas keindahan, kebenaran, kemewahan, dan suatu idealisme yang tidak dapat ditawar. Sedangkan mutu relatif bukan merupakan atribut dasar produk atau layanan, tetapi ia sebatas sesuatu yang dianggap berasal dari produk atau layanan tersebut. Mutu relatif bukan target akhir, ia hanya sebagai alat atau media yang telah dirumuskan untuk memenuhi standar mutu akhir yang ditetapkan.

Dari beberapa konsep yang diutarakan oleh para ahli di atas, maka dapat disimpulkan bahwa mutu merupakan ukuran kualitas sebuah produk yang berhubungan dengan hasil capaian suatu kegiatan produksi dan berimplikasi pada tingkat kepuasan pelanggan, apresiasi terhadap produk tertentu.

Mutu dalam konteks manajemen mutu terpadu di dunia pendidikan bukan sebatas suatu gagasan artifisial. Sejatinya, mutu adalah entitas filosofis dan metodologis guna membantu lembaga mengelola perubahan secara total dan sistemik melalui perubahan nilai-nilai, visi, misi dan tujuan. Kriteria mutu model ini penting mengingat dalam dunia pendidikan, mutu lulusan suatu sekolah dinilai berdasarkan atas kesesuaian kemampuan dan keterampilan yang dimilikinya dengan tujuan yang ditetapkan dalam kurikulum yang dipakai.

Menurut Sudradjad, pendidikan yang bermutu adalah model pendidikan yang mampu menghasilkan lulusan yang memiliki keunggulan dan kemampuan. ${ }^{11}$ Keunggulan

10 Usman, Manajemen. 2006. Teori, Praktek dan Riset Pendidikan. Jakarta: Bumi Aksara, h. 406.

11 Suderadjat. 2005. Manajemen Peningkatan Mutu Berbasis Sekolah; Peningkatan Mutu Pendidikan Melalui Implementasi KBK.Bandung: Cipta Lekas Garafika, h. 17. dan kemampuan, idealnya, dihargai publik di ranah akademik, teknikal-vokasional, atau kejuruan (keterampilan), yang dilandasi oleh mutu kompetensi profesional, personal, sosial, kepribadian, moral, serta akhlak mulia, yang keseluruhannya merupakan kecakapan hidup (life skill) di ranah moral, etis, dan sosial. Sudradjat lebih lanjut menegaskan bahwa pendidikan bermutu adalah pendidikan yang mampu menghasilkan manusia seutuhnya (insan kamil), yaitu manusia dengan kepribadian yang integratif, utuh, yaitu individu yang mampu memadukan unsur iman, ilmu, dan amal; antara ilmu, teknologi dan taqwa untuk standar lulusannya.

\section{Indikator Mutu Pendidikan}

Upaya meningkatkan mutu pendidikan harus terus-menerus dilakukan baik secara konvensional maupun inovatif. Menurut para ahli pendidikan, ada sejumlah indikator utama untuk menilai mutu pendidikan suatu lembaga atau satuan unit pendidikan. Indikatorindikator tersebut dapat disederhanakan ke dalam tiga rumpun, yaitu input, proses dan hasil. ${ }^{12}$

Input pendidikan dinyatakan bermutu, jika ia mampu berproses dengan baik. Indikator mutu madrasah di ranah input meliputi aspek visi, misi, tujuan, sasaran, struktur organisasi, input manajemen, input sumberdaya insani madrasah (mencakup kepala, guru, tenaga kependidikan, pengawai tata usaha dan siswa), sarana-prasarana, serta lingkungan madrasah. Aspek ini terlihat jelas biasanya dalam profil madrasah. Madrasah bermutu memiliki aset, infrastruktur, sarana-prasarana pembelajaran yang baik. Madrasah bermutu juga memiliki visi yang lebih tajam, cerdas, kreatif dan program kerja yang bagus sesuai dengan visi dan misi madrasah. Guru, pegawai serta siswa madrasah bermutu juga memiliki keunggulan kompetitif. Input madrasah bermutu terukur

${ }^{12}$ Hardy. 2007. Kebijakan Pembangunan Pendidikan Nasional. Jakarta: Depdiknas. 
dari etos sekolah dan semangat belajar siswa yang tinggi.

Proses pendidikan dinilai bermutu, jika ia mampu menciptakan suasana belajarmengajar yang aktif, kondusif, kreatif, dinamis, dan menyenangkan. Proses yang bermutu akan dapat tercapai jika seluruh anasir penyelenggara pendidikan (mencakup pemangku kebijakan dan kepentingan dan stake-holder) terlibat aktif sesuai porsi dan fungsinya dalam penyelenggaraan pendidikan itu. Intensitas dan kualitas partisipasi semua komponen dimaksud sangat menentukan mutu pendidikan. Faktor-faktor dalam proses tersebut mencakup berbagai input, seperti materi ajar, metodologi dan teknologi pengajaran, dukungan sumberdaya administrasi, sarana dan prasarana, sumberdaya lain, dan sebagainya, serta penciptaan suasana yang kondusif. Intinya, indikator mutu pendididkan di ranah proses mencakup proses dan suasana belajar dan mengajar. Keseluruhan proses tersebut harus ditopang dengan kualifikasi dan etos-dedikasi kerja yang baik dan luhur dari para pendidik, tenaga kependidikan, pegawai administrasi, kualitas kurikulum yang baik, manajemen dan administrasi pendidikan dan partisipasi sosial masyarakat yang maksimal dalam penyelenggaraan pendidikan.

Sedangkan mutu pendidikan dalam aspek hasil pendidikan mengacu pada prestasi yang dicapai madrasah dan siswa pada setiap kurun waktu tertentu, sesuai dengan serial rentang waktu yang menjadi basis evaluasi. Prestasi yang dicapai atau hasil capaian-prestasi siswa (student achievement) dapat berupa hasil tes kemampuan akademis (seperti ulangan harian, mingguan, tengah dan akhir semester, serta ujian akhir nasional). Prestasi bisa pula di bidang lainnya, non akademis, seperti prestasi dalam aktivitas sosial, atau lomba di suatu cabang olahraga, seni, budaya, dan keterampilan tambahan lain seperti di bidang komputer-sains, beragam lomba berbasis teknologi, jasa dan lain sebagainya. Bahkan prestasi madrasah dapat berupa kondisi yang tidak dapat tersentuh, atau abstrak seperti kenyamanan suasana sekolah, disiplin, kehangatan dan keakraban relasi, atmosfer sosial-etis saling menghormati, kebersihan, dan lain sebagainya, seperti peningkatan status akreditasi, dan penambahan jumlah siswa madrasah. ${ }^{13}$

\section{Metode Penelitian}

Penelitian ini merupakan studi evaluasi terhadap efektivitas pengelolaan dana BOS di MI/MTs. Studi ini menggunakan pendekatan survei dengan penekanan pada model analisis kuantitatif. Untuk menganalisis hambatan dan tantangan pengelolaan dana BOS, studi ini juga akan menggunakan model analisis kualitatif. Dengan model analisis statistik, studi ini akan memformulasikan model skema penyaluran dana BOS yang lebih kontekstual dan berkeadilan menurut jumlah siswa dan kondisi ekonomi madrasah.

Penelitian ini dilakukan pada bulan April sampai dengan bulan November 2013. Penelitian ini dilaksanakan di 12 propinsi, yaitu (1) Sumatera Utara, (2) Riau, (3) Sumatera Selatan, (4) Banten, (5) Jawa Barat, (6) Jawa Tengah, (7) Yogyakarta, (8) Jawa Timur, (9) Nusa Tenggara Barat, (10) Kalimantan Selatan, (11) Kalimantan Timur, dan (12) Sulawesi Selatan.

Populasi penelitian ini adalah seluruh Madrasah Ibtidaiyah (MI) dan Madrasah Tsanawiyah (MTs). Bingkai penarikan sampel survei ini mengacu pada daftar MI dan MTs yang dikeluarkan oleh Kementerian Agama Tahun 2012. Jumlah MI/MTs seluruh Indonesia (33 provinsi) tahun 2012 sebanyak 23.622 MI dan 14.022 MTs dengan total jumlah adalah 37.644 buah, dan rasio perbandingannya 62: 38. Jumlah sampel sebanyak 242 madrasah yang terdiri atas 144 MI dan 98 MTs. Sampel diseleksi secara purposif dengan pertimbangan variasi konteks madrasah (jumlah siswa, status

13 Suryosubroto. 2004. Manajemen Pendidikan di Sekolah. Jakarta: Rineka Cipta.

EDUKASI Volume 12, Nomor 1, Januari-April 2014 
hukum, dan akreditasi). Satuan unit analisisnya adalah madrasah dengan sumber data adalah sebagai berikut; (1) kepala madrasah, (2) guru, (3) siswa, (4) orangtua/wali siswa, (5) anggota komite sekolah, (6) masyarakat umum, dan (7) data kelembagaan madrasah.

Instrumen pengumpulan dalam survei ini berupa kuesioner, daftar isian dan pedoman interview. Kuesioner disiapkan untuk kepala madrasah, guru, siswa, orangtua, dan komite madrasah. Daftar isian dimaksudkan untuk mencatat hasil mendokumentasikan data statistik kelembagaan MI/MTs, dan pedoman interview untuk panduan interview mendalam dengan kepala madrasah.

Sementara itu data kuantitatif diolah dengan menggunakan SPSS versi 19. Data dientri dan dianalisis oleh tim khusus, agar tidak terjadi kesalahan pada tahap pengolahan dan analisis data. Analisis survei ini lebih difokuskan pada model analisis kuantitatif, terutama untuk mengkritisi dampak dana BOS terhadap mutu madrasah. Analisis regresi dimaksudkan untuk mengestimasi besaran pengaruh jumlah guru negeri-swasta terhadap persentase alokasi dana BOS untuk belanja pegawai. Fokus analisis terakhir ini sangat penting untuk menilai besar pengaruh jumlah guru honorer terhadap pemanfaatan dana BOS. Selama ini, madrasah umumnya mengalami kesulitan untuk membayar gaji-honor guru honorer dengan standar penghargaan yang layak dan manusiawi.

\section{HASIL DAN PEMBAHASAN}

Hasil penelitian akan disajikan dengan sistematika berikut: Pertama, analisis data diawali dengan evaluasi isu-isu di ranah perencanaan (penyusunan rencana kegiatan dan anggaran madrasah, sosialisasi, publikasi keberadaan dana BOS, penyelenggaraan rapat pembahasan rencana penggunaan dana BOS bersama stakeholder madrasah, terutama wali siswa dan komite, dan pemutakhiran data siswa). Kedua, analisis data difokuskan pada pelaksanaan penggunaan dana BOS yang mencakup alokasi dana BOS menurut jenis belanja, evaluasi proses pencairan, transparansi, akuntabilitas, dan kelegaan pihak madrasah untuk melibatkan perwakilan guru, wali siswa dan komite dalam pengelolaan dana BOS. Ketiga, analisis data akan mencermati ranah pemantauan pelaporan. Keempat, analisis data akan mengkritisi dampak BOS terhadap keberadaan madrasah. Terakhir, evaluasi umum terhadap kebijakan publik mengenai skema distribusi dana BOS.

\section{Perencanaan}

\section{Penyusunan RKAM}

Menurut Petunjuk Teknis Pelaksanaan BOS pada Madrasah Negeri Tahun Anggaran 2012, madrasah calon penerima dana BOS harus menyusun rencana kegiatan dan anggaran madrasah (RKAM). Data menunjukkan bahwa para responden (kepala, guru dan komite), menyatakan mereka rutin menyusun RKAM, paling tidak sekali dalam dua tahun. Data ini memperlihatkan bahwa madrasah cukup baik mempersiapkan penggunaan dana BOS.

Tidak hanya rutin menyusun RKAM, madrasah juga intensif melibatkan para stakeholder dalam penyusunan RKAM. Sebanyak 8, 96\% kepala madrasah mengaku pernah, minimal dua kali, melibatkan perwakilan guru, komite dan wali siswa dalam penyusunan RKAM. Pengakuan kepala madrasah diamini oleh responden guru dan komite. Paling tidak, $\pm 86 \%$ guru dan $90 \%$ komite mengaku pernah dilibatkan dalam kegiatan penyusunan RKAM.

Bagaimana intensitas madrasah menyusun RKAM yang terpadu ke dalam rencana penggunaan dana BOS? Hasil penelitian menujukkan bahwa madrasah selalu rutin menyusun RKAM terpadu dengan rencanaan penggunaan dana BOS. Pola penilaian responden terhadap aspek ini sangat seragam. Fakta ini bisa dijadikan sebagai satu indikator objektivitas evaluasi persiapan penggunaan dana BOS. Mayoritas responden ( $\pm 98 \%$ ) baik 
kepala, guru atau komite, mengaku pernah menyusun RKAM yang terpadu ke dalam rencana penggunaan dana BOS.

Ringkasnya, temuan ini menegaskan bahwa perencanaan penggunaan dana BOS sudah dilakukan dengan baik dan telah melibatkan para guru dan komite pada tahap paling awal perencanaan penggunaan dana BOS. Dengan kata lain dapat disimpulkan bahwa perencanaan penggunaan dana BOS di madrasah telah dirintis dengan baik.

\section{Publikasi dan Sosialisasi Program Dana BOS}

Program BOS sudah menjadi isu publik yang lumrah dibicarakan para warga madrasah. Mayoritas responden (> 96\%) mengaku bahwa madrasah selalu mengumumkan rencana penggunaan dana BOS kepada masyarakat terutama guru, komite, dan wali siswa. Dengan kata lain, informasi tentang keberadaaan dana BOS sangat diketahui masyarakat umum. Forum rapat pimpinan madrasah dengan orangtua siswa di awal semester menjadi media yang lazim dan efektif digunakan pihak madrasah untuk menyampaikan program dana BOS. Secara keseluruhan, hasil survei ini membuktikan bahwa kinerja tim BOS madrasah sangat baik dalam mempublikasikan BOS kepada warga madrasah terutama wali siswa.

\section{Pemutakhiran Data Siswa}

Jumlah siswa menjadi standar dasar untuk menghitung besaran dana BOS yang diterima madrasah. Menurut ketentuan pemerintah, BOS diberikan merata pada setiap siswa (kayamiskin). Untuk kepentingan tersebut, setiap madrasah diwajibkan memutakhirkan data jumlah siswa setiap tahun bahkan setiap kali pencairan dana BOS. Data memperlihatkan bahwa madrasah sangat baik dalam memperbarui data siswa dan mereka rutin melakukannya setiap semester.

Ringkasnya, di level perencanaan, kinerja tim BOS madrasah mengelola dana BOS sudah sangat baik. Semua responden (kepala, guru, wali siswa, dan komite madrasah) menegaskan hal ini. Hasil survei ini searah dengan hasil studi lain yang menegaskan bahwa program BOS sudah tersosialisasi dengan baik kepada warga madrasah.

\section{Pelaksanaan}

\section{Penggunaan alokasi dana BOS}

Bahasan berikut akan menyajikan data tentang penggunaan dana BOS sesuai peruntukannya. Menurut ketentuan, dana BOS hanya boleh digunakan untuk kebutuhan belanja non personalia seperti membayar gaji-honor guru. Untuk alasan tertentu, dana BOS boleh digunakan untuk membayar gaji guru dan tenaga kependidikan honorer dengan jumlah persentase yang tidak melebihi $20 \%$ dari keseluruhan dana BOS.

Tabel 1:

Rata-rata Persentase Alokasi Dana BOS untuk Beragam Jenis Belanja dan Tahun

\begin{tabular}{|l|r|r|r|r|}
\hline Uraian & 2010 & 2011 & 2012 & 2013 \\
\hline 1. Belanja pegawai & 56.27 & 55.60 & 52.35 & 47.66 \\
\hline 2. Belanja kebutuhan rutin kantor & 7.78 & 8.29 & 8.56 & 8.44 \\
\hline $\begin{array}{l}\text { 3. Belanja kebutuhan daya- } \\
\text { jasa }\end{array}$ & 2.38 & 3.00 & 2.93 & 4.39 \\
\hline 4. Belanja KBM & 17.21 & 16.05 & 15.32 & 15.47 \\
\hline 5. Belanja kegiatan kesiswaan & 8.82 & 9.40 & 9.96 & 8.90 \\
\hline 6. Belanja perpustakaan & 6.64 & 6.52 & 6.94 & 7.43 \\
\hline 7. Belanja subsidi siswa miskin & 5.00 & 5.62 & 7.63 & 10.35 \\
\hline 8. Belanja pemeliharaan & - & 5.66 & 5.48 & 6.95 \\
\hline 9. Belanja Lain-lain & 6.54 & 7.60 & 7.86 & 9.08 \\
\hline N (madrasah) & 38 & 74 & 86 & 84 \\
\hline
\end{tabular}

Data diatas menunjukkan bahwa: Pertama, penggunaan dana BOS sangat didominasi untuk hajat belanja pegawai. Penggunaan dana BOS untuk keperluan belanja ini dalam tiga tahun terakhir, tanpa memilah status madrasah, mencapai rata-rata kisaran di atas 50\%, kecuali pada tahun anggaran 2013. Besarnya alokasi persentase belanja pegawai ini tidak bisa dihindari karena madrasahmadrasah, terutama swasta menghadapi problem keterbatasan guru-guru negeri. Setiap madrasah negeri dan swasta memiliki guru 
honorer minimal 10 orang. Bahkan mayoritas dari guru-guru honorer tersebut masih belum lulus sertifikasi profesi guru. Akibatnya tingkat kesejahteraan mereka relatif kurang, dan dana BOS menjadi substitusinya.

Kedua, belanja untuk keperluan kegiatan belajar mengajar, belanja subsidi (bantuan) untuk siswa kurang mampu, dan belanja perpustakaan masih sangat sedikit. Padahal, tiga pos belanja ini menjadi prioritas utama untuk mendapatkan alokasi dana BOS.

Ketiga, alokasi untuk belanja kegiatan kesiswaan sudah cukup baik; rata-rata alokasinya per tahun sudah berkisar $10 \%$. Ini artinya bahwa pihak madrasah cukup bersikap affirmatif untuk mendukung kegiatan kesiswaan. Keempat, besaran belanja lainlain menarik untuk dicermati. Pos belanja ini menampungsegalajenispengeluaranyangtidak dapat, atau minimal sulit untuk bisa ditampung dalam akun-akun jenis belanja sebelumnya yang sangat jelas, tegas, dan ketat. Pos akun belanja lain-lain mencakup belanja barang peralatan kantor non hajat pembelajaran dan non kebutuhan rutin, biaya pengelolaan operasional dana BOS, transport pimpinan ke pertemuan yang dihadiri, perbaikan peralatan kantor dan lain sebagainya. Dalam konteks ini, ada trend peningkatan alokasi belanja pos ini pada tiga tahun terakhir. Jika ini dicermati, secara manajerial dan administratif keuangan, pola penggunaan pos belanja lain-lain ini bisa menjadi indikator bahwa dana BOS sudah mulai sedikit banyak disalah-gunakan, atau dimanipulasi, minimal untuk pos belanja hajat yang tidak direkomendasikan dalam Petunjuk Pelaksaan Dana BOS.

\section{Transparansi, Akuntabilitas, dan Objektivitas Pengelolaan Dana BOS}

Secara normatif, suatu peraturan harus ditaati, termasuk peraturan tentang pengelolaan dana BOS. Petunjuk Teknis Pelaksanaan Dana BOS tahun 2012 dengan rinci dan jelas mengatur ketentuan penggunaan dana BOS. Prinsi-prinsip transparansi, akuntabilitas, keadilan, keberpihakan pada kelompok kurang mampu, dan sinergitas madrasah dengan stakeholder menjadi acuan yang harus ditaati dalam pengelolaan dana BOS. Ada beberapa indikator untuk menilai sejumlah butir normatif di atas seperti disajikan pada bahasan berikut ini.

Waktu pencairan dana BOS menjadi momentum krusial untuk kelancaran pengelolaan dana BOS. Menurut peraturan umum, pencairan dana BOS dilakukan secara bertahap dalam empat periode (triwulan pertama, kedua, ketiga dan keempat). Namun data hasil penelitian menunjukkan bahwa mayoritas responden, sesuai pengalaman keterlibatannya dalam pengelolaan dana BOS, menilai bahwa pencairan dana BOS umumnya tidak tepat waktu, sering telat, terutama untuk periode triwulan ke I (Januari-Maret).

Data hasil interview menunjukkan bahwa keterlambatan pencairan dana BOS tersebut berhulu dari kebijakan keuangan nasional. Di bulan-bulan pertama, awal tahun, kebijakan 'membintangi' beberapa pos anggaran non prioritas selalu dilakukan oleh pemerintah pusat. Bahkan 'bintang' tersebut baru dicabut mulai Maret, bahkan sampai melewati bulan tersebut. Oleh sebab itu, pencairan dana BOS triwulan ke I umumnya terlambat setiap tahun. Kritik terhadap keterlambatan pencairan ini merata disuarakan oleh nyaris semua responden dan narasumber.

Mayoritas responden menilai bahwa Tim BOS Kantor Kementerian Agama cukup positif membantu pencairan dana BOS. Tim Kementerian tidak dinilai memperlambat proses pencairan. Oleh sebab itu, masalah keterlambatan pencairan dana BOS lebih disebabkan oleh faktor politik keuangan nasional. Ringkasnya, solusi percepatan waktu pencairan dana BOS terutama untuk triwulan 1 tidak mungkin bisa diatasi di level Kantor Kementerian Agama. Alhasil, keterlambatan pencarian dana BOS terus akan berlanjut setiap tahun ketika kebijakan pemerintah 
pusat tetap membintangi beberapa anggaran non prioritas, termasuk dana BOS.

Masalah keuangan sangat rentan untuk diselewengkan, dan administrasinya sering tidak mudah untuk diakses dan cenderung tertutup. Bagaimana kesan responden terhadap transparansi pengelolaan dana BOS di level Tim madrasah? Kinerja transparansi Tim pelaksana BOS madrasah sudah sangat baik, dan dinilai terbuka, walaupun minimal $20 \%$ responden guru, dan sepertiga responden komite menilai bahwa pihak pelaksana dana BOS di level madrasah masih kurang terbuka dalam hal pengelolaan dana BOS. Kesan kurang baik ini menjadi pekerjaan khusus Tim dana BOS level madrasah untuk memperbaiki kinerja mereka di kemudian hari.

Penilaian responden terhadap akuntabilitas pengelolaan dana BOS madrasah juga sangat positif. Penilaian positif terhadap akuntabilitas ini merata di setiap rumpun responden. Kualitas transparansi dan akuntabilitas pengelolaan dapat juga dinilai dari sisi penerimaan warga madrasah terhadap eksistensi pengelolaannya. Protes warga terhadap pengelolaan dana BOS dapat menunjukan tingkat kualitas kinerja Tim dana BOS madrasah. Walaupun protes pernah terjadi, namun skala dan intensitasnya tidak cukup mengkhawatirkan, masih dalam batas kewajaran, mengingat kebijakan finansial sering memicu pro dan kontra. Terlepas dari pemaknaan di atas, data tentang protes ini harus juga dijadikan indikator bahwa kinerja Tim dan BOS madrasah masih menyimpan persoalan yang mudah disalah-tafsirkan.

\section{Pelaporan Pengelolaan Dana BOS}

Apakah pelaporan pengelolaan dana BOS juga dinilai positif? Sisi positif tentang kinerja pengelolaan dana BOS menurut responden juga nampak pada aspek objektivitas pelaporan pengelolaan dana BOS. Mayoritas responden guru dan komite menilai bahwa tim BOS madrasah sudah objektif dalam pengelolaan BOS baik di level perencanaan, pelaksanaan dan juga pelaporan. Responden umumnya menilai laporan pengelolaan BOS telah dibuat apa adanya, tanpa manipulasi untuk pembenaran penyimpangan.

Apakah Tim pengelola BOS madrasah rutin membuat laporan? Menurut ketentuan teknis pelaksanaan BOS, madrasah membuat laporan pengelolaan BOS secara periodik sesuai tahapan waktu pencairan dana, dan juga harus mempublikasikannya kepada masyarakat. Tim BOS madrasah dinilai selalu rutin membuat laporan lengkap pengelolaan dana BOS minimal sekali setahun. Bahkan laporan tersebut dibuat tepat waktu.

Publikasi laporan pengelolaan dana BOS tidak hanya bersifat umum. Tim pengelolaan dana BOS madrasah sudah sangat terbuka dalam hal publikasi rincian penggunaan dana BOS sesuai dengan jenis belanjanya. Bahkan laporan rincian ini dibuat rutin sesuai dengan standard operating procedure (SOP) yang telah dbuat oleh Tim BOS Pusat. Hanya sebagian kecil responden guru dan komite yang menilai bahwa Tim BOS madrasah tidak membuat laporan pengelolaan dana BOS sesuai ketentuan.

Bagaimanana pengawasan dan pemantauan pelaksanaan dana BOS? Penilaian responden terhadap pengawasan dan pemantauan pelaksanaan BOS cukup baik. Di sini, minimal $75 \%$ dari setiap basis kelompok responden mengaku bahwa mereka sering ikut terlibat memantau kegiatan pelaksanaan dana BOS, tentunya dengan skema, pola dan fokus pemantauan yang berbeda. Partisipasi banyak komponen warga madrasah ini tentu akan meningkatkan kualitas kinerja positif pengelolaan dana BOS.

Apakah peran positif dan aktif di level Tim BOS Kantor Kementerian Agama Pusat juga terlihat di ranah pemantauan dan pengawasan dana BOS? Data menunjukkan bahwa minimal sepertiga dari total responden dengan beragam latar belakang dan fungsi, mengaku bahwa Tim BOS Kantor Kementerian Agama sering aktif ikut memantau pelaksanaan dana BOS. Peran 
aktif pemantauan ini bisa dijadikan indikator untuk menegaskan bahwa pelaksanaan program dana BOS telah berjalan dengan baik dan sesuai dengan petunjuk teknis pemantauan yang ditetapkan dalam buku Pedoman Teknis Pelaksanaan BOS.

\section{Problematika Administratif dan Manajerial Pengelolaan Dana BOS}

Jika dikilas balik, secara umum, kinerja pelaksanaan dana BOS di level Tim madrasah, secara tentatif dapat dinilai, telah berjalan dengan sangat baik. Formula distribusi besaran jumlah dana BOS per madrasah, oleh mayoritas responden dinilai sudah cukup adil dengan menggunakan acuan jumlah siswa per madrasah. Artinya, semakin banyak jumlah siswa, maka semakin banyak dana BOS yang akan diterima oleh madrasah dimaksud. Sebaliknya, semakin sedikit jumlah siswa, maka semakin sedikit dana BOS yang akan diterima. Bahkan mayoritas responden kepala, guru dan komite madrasah mengusulkan agar formula yang dipakai saat ini terus dipertahankan. Namun di sisi lain, mereka juga tetap menyarankan agar pemerintah serius mempertimbangkan isu keterbatasan jumlah guru PNS di madrasah, selain juga membantu percepatan sertifikasi guru-guru yang belum lulus.

Apakah besaran dana BOS (Rp. 580.00 per siswa MI, dan Rp. 710.000 untuk siswa MTs) yang diterima setiap siswa saat ini sudah cukup memadai? Rata-rata sekitar setengah dari total responden menilai jumlah tersebut masih belum cukup memadai. Jumlah itu dinilai masih cukup memberatkan beban madrasah, karena dana BOS yang belum memadai itu, madrasah, khususnya negeri, dilarang untuk memungut semua jenis iuran dari wali siswa. Beban ini semakin berat bagi madrasah swasta, karena ia harus membayar gaji gurunya tanpa subsidi pemerintah, dan di sisi lain, para guru tersebut terbukti umumnya masih banyak yang belum lulus sertifikasi. Larangan semua jenis pungutan dimaksud, menurut komentar banyak narasumber dalam interview mendalam, dinilai sebagai satu indikator dasar bahwa pemerintah kurang memperhatikan kesejahteraan guru. Oleh sebab itu, jika pendidikan dasar 9 tahun harus digratiskan oleh pemerintah, mereka mengusulkan agar besaran dana BOS per siswa di tahun mendatang ditambahkan.

\section{Dampak Dana BOS}

Dampak pengelolaan dana BOS dapat disimak dengan beberapa indikator. Survei ini menggunakan indikator berikut untuk menilai dampak dana BOS terhadap mutu madrasah, yaitu (a) peningkatan status akreditasi madrasah, (b) peningkatan jumlah siswa, (c) jumlah siswa tinggal kelas dan putus sekolah, (d) pengurangan bebas biaya sekolah, (e) peningkatan semangat belajar dan etos sekolah siswa, dan (f) peringanan beban finansial madrasah untuk membayar gaji guru-guru dan tenaga kependidikan honorer.

Pemberian dana BOS sangat berpengaruh positif terhadap mutu dan eksistensi madrasah. Mungkin perubahan status hukum madrasah dari status swasta menjadi negeri tidak relevan untuk dijadikan indikator untuk menilai dampak positif dana BOS terhadap peningkatan mutu madrasah. Namun, hasil studi ini membuktikan bahwa peningkatan status hukum tersebut sebesar $1.7 \%$ sejalan dengan pemberian dana BOS.

Dampak positif dana BOS terhadap mutu madrasah juga diperlihatkan oleh peningkatan status akreditasi madrasah. Status akreditasi madrasah meningkat secara signifikan. Jumlah madrasah yang belum terakreditasi dari 66 buah sebelum survei, (data tahun 2011), tersisa hanya satu madrasah, turun drastis $8.7 \%$ saat survei. Peningkatan status akreditasi juga terjadi ke level yang lebih tinggi. Peningkatan status akreditasi terlihat jelas di setiap level akreditasi. Ringkasnya, dengan dana BOS, peningkatan status akreditasi madrasah sangat signifikan dan sulit untuk dibantah. Hal ini terjadi karena dengan dukungan dana BOS, pihak madrasah memiliki dana tambahan untuk proses penyelenggaran akreditasi. 
Peningkatan status madrasah (sisi hukum dan akreditasi) juga meningkatkan citra dan pamor mutu madrasah di mata masyarakat luas. Kenyataan ini pasti akan berdampak turunan pada etos masyarakat untuk menyekolahkan anak-anak ke madrasah. Terbukti bahwa jumlah siswa madrasah-madrasah yang diteliti meningkat tajam. Jumlah siswa meningkat $10.75 \%$ dalam dua tahun terakhir. Ini fakta yang sangat menggembirakan sebagai bukti dampak positif pengelolaan dana BOS terhadap mutu madrasah. Sementara itu, angka jumlah siswa tinggal kelas sangat rendah, di bawah rata-rata 5 orang di setiap madrasah; begitu juga untuk kasus siswa putus sekolah.

Seperti dijelaskan terdahulu, sebagian dana BOS digunakan untuk mendukung kegiatan kesiswaaan dalam wujud lomba yang diikuti oleh siswa madrasah. Capaian prestasi untuk jenis lomba dievaluasi juga sangat baik.

Apakah pemberian BOS berdampak positif pada peningkatan etos sekolah dan belajar siswa? Pertama, $72 \%$ responden wali siswa (201 orang) mengaku bahwa dana BOS sangat membantu meringankan biaya sekolah anakanaknya; $75 \%$ mengaku dana BOS cukup mampu meningkatkan motivasi belajar anak-anaknya; dan $88 \%$ mengaku dana BOS cukup bermanfaat untuk mendorong etos sekolah anak-anak. Pengakuan yang sama juga diungkapkan responden siswa. Mereka mengakui bahwa pendidikan gratis, dan pemotongan biaya sekolah sangat bermanfaat untuk peningkatan motivasi belajar dan etos sekolah. Dengan dana BOS, mereka mengaku bahwa sekolah akhirnya telah menggratiskan biaya pendidikan mereka. Ini fakta dari keberkahan dana BOS yang sangat disyukuri oleh orangtua dan para siswa.

Kedua, dampak positif dana BOS pada beban finansial madrasah juga telah diamini responden kepala dan guru madrasah. Mayoritas (> 90\%) responden mengaku bahwa keberadaan program dana BOS sangat membantu madrasah membayar gaji guru dan tenaga kependidikan honorer, membiayai beban finansial lainnya terutama untuk proses KBM, pengadaan buku- buku teks, dan biaya kegiatan kesiswaan. Dengan kata lain, mutu madrasah meningkat, dan kesejahteraan guru honorer, terutama, dengan standar gaji yang layak, juga digoreskan oleh program dana BOS.

Keempat, pengelolaan dana BOS bukan tanpa kekurangan dan kendala. Hasil analisis kualitatif terhadap data hasil interview tergali beberapa kendala yang dihadapi madrasah dalam pengelolaan dana BOS. Kendala tersebut dapat didaftar sebagai berikut; ada yang sifatnya klasik, dan ada juga yang bersifat polisional; (a) keterlambatan waktu pencarian dana BOS, (b) jumlah satuan dana BOS yang kurang memadai untuk madrasah dengan siswa yang sangat sedikit, (c) kebijakan distribusi dana BOS yang mengabaikan variasi jumlah guru, tenaga kependidikan dan pegawai honorer, dan (d) manajemen pengelolaan BOS yang terlalu berpusat pada peran sentral pimpinan.

\section{PENUTUP}

\section{Kesimpulan}

1. Kinerja pengelolaan dana BOS sudah sangat positif. Sisi positif dari pengelolaan dana BOS ini terlihat dari jenjang persiapan, proses pelaksanaan, dan kegiatan pasca pelaksanaan, dampak turunannya, dan evaluasi umum terhadap kinerja Tim BOS madsarah.

2. Dana BOS berdampak sangat positif terhadap peningkatan mutu madrasah yang terukur dengan indikator peningkatan status akreditasi madrasah, peningkatan jumlah siswa, dan jumlah siswa tingal kelas dan putus sekolah. Dampak positif BOS juga terrekam dari fakta jejak prestasi siswa madrasah di banyak dan variasi lomba. Selain itu, dana BOS mampu meningkat etos sekolah, dan semangat belajar siswa.

3. Pelaksanaan dana BOS tidak selamanya berjalan mulus tanpa hambatan. Pencairan dana BOS yang cenderung terlambat untuk periode triwulan pertama menghambat madrasah untuk menyelenggarakan 
kegiatan pendidikan di awal semester. Proses, prosedur dan detail norma akuntansi pelaporan pertanggungjawaban penggunaan dana BOS juga dikeluhkan banyak pihak madrasah. Selain itu, keterbatasanjumlah danaBOSjuga dikeluhkan tidak cukup memadai guna membiayai seluruh hajat belanja madrasah. Faktor terakhir ini sebetulnya bukan kesalahan legislasi BOS, mengingat dana BOS hanya sebagai bantuan finansial tambahan. Pihak madrasah terlalu banyak berharap kepada ketercukupan dana BOS untuk mengatasi segala kebutuhan finansial madrasah.

\section{Rekomendasi}

Dari hasil penelitian ini dapat direkomendasikan beberapa hal sesuai target lembaga yang diharapkan menindaklanjuti rekomendasi ini.

a. Membuat standar minimal dari dana BOS yang akan didapat oleh setiap madrasah tanpa melihat jumlah siswa. Besaran dana yang diterima harus berpijak pada acuan kemampuan madrasah mampu memberi standar pelayanan minimal kepada masyarakat.

b. Kebijakan affirmatif untuk kesejahteraan guru dan tenaga kependidikan lainnya harus diprioritaskan dengan percepatan proses sertifikasi profesi guru-guru swasta dan honorer di madrasah, atau pengangkatan guru honorer menjadi PNS.

c. Perbaikan sistem pencairan dana BOS sehingga pencairan tidak terlambat terutama pada awal tahun.

d. Partisipasi aktif dan peran kontrol Kantor Kementerian Agama dalam pengelolaan perlu ditingkatkan.

\section{SUMBER BACAAN}

Bray, Marl (1996): Decentralization of Education: Community Finnacing. Washington DC, World Bank.

Hardy, Rampay (2007): Kebijakan Pembangunan Pendidikan Nasional. Jakarta: Depdik-nas. Haris, Abdul dan Nurhayati B, Manajemen Mutu Pendidikan, (Jakarta: 2010).

Petunjuk Teknis (2007): Pelaksanaan Bantuan Operasional Sekolah (BOS) pada Madrasah Negeri Tahun Anggaran .Jakarta: Direktorat Jenderal Pendidikan Islam, Kementerian Agama.

Rebore, Ronald W. (1985): Educational Administration: A Management Approach. Engle-wood Cliffs: Prentice Hall.

Saharudin dan Lukman Hakim (2011): Bantuan Operasional Sekolah: Konsistensi Mandat, Keberlanjutan, dan Akuntabilitas . Jakarta: Pattiro.

Simanjuntak, Payaman J. (1998): Pengantar Sumber Daya Manusia. Jakarta: FEUI.

Suderadjat, Hari (2005) Manajemen Peningkatan Mutu Berbasis Sekolah: Peningkatan Mutu Pendidikan Melalui Implementasi KBK. Bandung: Cipta Lekas Grafika.

Supriadi, Dedi (2004): Satuan Biaya Pendidikan Dasar dan Menengah. Bandung: PT Remaja Rosda-karya.

Suryosubroto, B. (2004): Manajemen Pendidikan di Sekolah. Jakarta: Rineka Cipta.

Syafrudin (2003), Manajemen Mutu Terpadu dalam Pendidikan. Jakarta: Grasindo.

Usman, Husaini (2006): Manajemen: Teori, Praktek dan Riset Pendidikan. Jakarta: Bumi Aksara. 